\title{
Biserica Ortodoxă Română și învățămîntul universitar: între libertate academică și constrîngere
}

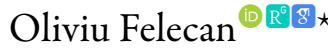 \\ Universitatea Tehnică din Cluj-Napoca, Centrul Universitar Nord Baia Mare, Facultatea de Litere, Str. Victoriei 76, \\ 430122 Baia Mare, România
}

\author{
Despre articol \\ Istoric: \\ Primit 10 februarie 2020 \\ Acceptat 26 martie 2020 \\ Publicat 10 iunie 2020 \\ Cuvinte-cheie: \\ învățămînt teologic \\ libertate universitară \\ biserică \\ offensiphobia
}

\begin{abstract}
Rezumat
Prezentul studiu este susceptibil de a stîrni anumite controverse, deoarece tratează probleme ale felului în care sînt înțelese libertăți academice, libertăți de exprimare într-o țară a Uniunii Europene, în secolul XXI, în care Biserica Ortodoxă Română (BOR) încearcă să impună anumite restricții, bazate pe abuzul de autoritate, de putere dominantă. Ingerința BOR în mediul universitar, într-o formă continuată, poate fi interpretată ca un atac susținut la autonomia universitară, ca o dorință de a-și subordona și de a controla mediul academic, sub pretextul gestionării problemelor teologice. Activitatea științifică și didactică a teologilor ar trebui să depindă exclusiv de meritele acestora, nu de obținerea unui aviz din partea unui episcop care, de cele mai multe ori, nu face parte din sistemul universitar.
\end{abstract}

\section{Preliminarii. Biserica Ortodoxă și societatea românească}

În societatea românească se înregistrează un fenomen specific unei democrații în formare: poziționarea unor instituții mai presus de lege, derogarea lor de la anumite prevederi legale sau influențarea unor decizii în funcție de autoritatea pe care o dețin în societate și asupra factorului politic, în special. Un exemplu elocvent în acest sens este Biserica Ortodoxă Română (BOR) care, bazîndu-se pe faptul că România este una dintre cele mai religioase țări din lume ${ }^{1}$, în care procentul de ortodocși deține $86,45 \%^{2}$, profită de poziția dominantă și încearcă să-și făurească un „cadru legislativ” propriu, pentru a-și urmări interesele și a-şi întări privilegiile. Un exemplu elocvent îl constituie neimpozitarea veniturilor bisericești, deși BOR deține o avere considerabilă, cuantificabilă nu doar în lăcașuri de cult (peste 18000), ci și în terenuri agricole, păduri, clădiri (hoteluri) etc. [online].

BOR a știut să-și negocieze întotdeauna privilegiile și, poziționîndu-se invariabil de partea puterii ${ }^{3}$, a obținut tot ce a dorit. Fiind considerată agentul electoral ideal, prin influența avută asupra electorilor, niciun partid nu a îndrăznit să-i stea în cale ${ }^{4}$ și, prin complicitate, Biserica Ortodoxă și-a consolidat poziția dominantă în România democratică.

Controlul total pe care BOR îl dorește asupra societății și a ideilor propagate se întrevede și în domeniul educațional, prin introducerea orelor de religie timp de 13 ani în sistemul preuniversitar. Se induce o confuzie între religie și religiozitate, pentru a avea cadre didactice cu pregătire teologică în toate școlile

*Adresă de corespondență: olifelecan@yahoo.com.

${ }^{1}$ Potrivit „Global Index of Religion and Atheism - 2012”, realizat de institutul Gallup International, România se situează pe locul șapte în lume și primul din Uniunea Europeană în ce privește religiozitatea, 89\% din populație declarîndu-se religioasă [online].

${ }^{2}$ Informațiile sînt preluate de la Institutul Național de Statistică al României, care a publicat datele aferente recensământului din anul 2011 [online].

${ }^{3} \mathrm{O}$ analiză lucidă a implicării BOR în viața publică din ultimele decenii este făcută de către Schmitt (2018) în cotidianul elvețian „Neue Zürcher Zeitung”.

${ }^{4}$ Indiferent de partidele/coalițiile care s-au succedat la putere, BOR a primit fonduri publice consistente (pentru construcția bisericilor și mănăstirilor, de ex.), în timp de infrastructura țării a fost neglijată. 
din țară și pentru a deține controlul asupra acestora și, implicit, al elevilor. Presiunea pusă pe programa școlară în perioada posttotalitară este completată de anumite prevederi (protocoale, hotărîri) care, deși nu au caracter de lege, sînt respectate de conducătorii instituțiilor de învățămînt, atît la nivel preuniversitar, cît și la nivel universitar. Într-un studiu recent (v. Felecan \& Munteanu Siserman, 2018, p. 173-184), am analizat cum, prin Protocolul cu privire la predarea disciplinei religie - cultul ortodox în învățămîntul preuniversitar și la organizarea învățămîntului teologic ortodox preuniversitar și universitar, încheiat între Ministerul Educației Naționale, Patriarhia Română și Secretariatul de Stat pentru Culte în anul 2014, se „încalcă autonomia universitară, se anulează autoritatea ARACIS ${ }^{5}$ - ca factor decident pentru înființarea / desființarea unor specializări din învățămîntul superior din țara noastră -, se nesocotesc comisiile de concurs pentru ocuparea posturilor didactice, se limitează dreptul de a promova pe un post sau de a susţine abilitarea, care ar trebui să depindă exclusiv de activitatea științifică și didactică a candidaților, nu de obținerea unui aviz din partea unui episcop care nu face parte din sistemul universitar”. Deși respectivul protocol nu este valid juridic ${ }^{6}$ și are prevederi contrare cadrului legislativ românesc, este respectat în mai multe universități și produce efecte contrare spiritului academic european, dar și libertăţii universitare din România sau libertăţii de conștiință.

\section{Corpus}

În studiul de față vom analiza cîteva paragrafe dintr-un document oficial cu caracter administrativ, care vizează sistemul educațional, în general, şi cadre universitare cu o pregătire teologică ortodoxă, în special: o Hotărîre a Sfîntului Sinod ${ }^{7}$ al Bisericii Ortodoxe Române, dată în ședința de lucru din 24 mai 2018 (Temei nr. 4761 / 2018). Redăm, în continuare, două paragrafe, din cele patru:

1. Sfîntul Sinod aprobă ca, pentru a fi membri în asociații sau fundații teologice ortodoxe, interconfesionale sau interreligioase internaţionale, ori pentru a participa la evenimente teologice internaționale ca vorbitori, teologii ortodocși români să obțină în prealabil acordul scris al Chiriarhului lor şi binecuvintarea (aprobarea) Patriarhului României;

3. Sfîntul Sinod aprobă ca, pentru a obține binecuvîntarea (aprobarea) Patriarhului României de a participa la evenimente teologice internaționale ca vorbitori, teologii ortodocși români să înainteze la Sectorul teologic educațional al Administrației Patriarhale o solicitare scrisă împreună cu acordul scris al Chiriarhului lor, cu un Curriculum Vitae și cu o descriere a temei evenimentului și a subiectului comunicării pe care urmează să o susțină.

\section{Analiza textului}

Primul paragraf poate fi suspectat de neconstituționalitate. În ciuda faptului că dreptul la asociere este stipulat în Constituția României (Art. 40 (1): „Cetățenii se pot asocia liber în partide politice, în sindicate, în patronate și în alte forme de asociere." [online]), Sfîntul Sinod al BOR îngrădește acest drept și îl condiționează de acordul ierarhic al superiorului ecleziastic. Altfel spus, un episcop se poate erija ca fiind superior cadrului legislativ în vigoare, ceea ce pare de-a dreptul hilar. În mod normal, un cadru didactic

\footnotetext{
${ }^{5}$ Agenția Română de Asigurare a Calității în Învățămîntul Superior (ARACIS) este instituția publică însărcinată prin lege cu evaluarea, acreditarea și autorizarea temporară a învățămîntului superior din România. ARACIS este membră deplină a European Association for Quality Assurance in Higher Education (ENQA) și este înregistrată în European Quality Assurance Register for Higher Education (EQAR).

${ }^{6} \mathrm{Nu}$ a fost publicat în „Monitorul Oficial al României”, așa cum se impune la orice act juridic. Această publicație a statului, aflată în subordinea guvernului, publică actele prevăzute de Constituție, legi, hotărîri, moțiuni, decrete, ordonanțe de urgență, acte normative și alte acte menționate de legea de organizare și funcționare a Monitorului Oficial.

${ }^{7}$ Sfîntul Sinod este cea mai înaltă autoritate a Bisericii Ortodoxe Române, pentru toate problemele dogmatice și canonice, precum și pentru cele bisericești de orice natură. Este prezidat de patriarhul României. Sinodul este format din toți mitropoliții, arhiepiscopii, episcopii, episcopii vicari și arhiereii vicari ai Bisericii Ortodoxe Române [online].
} 
universitar, chiar și teolog, ar trebui să aibă dreptul de a alege, în funcție de preocupările sale, de disciplinele pe care le predă, organizațiile profesionale la care să se afilieze, fără nicio restricție. Condiționarea dreptului la liberă asociere de acordul scris al chiriarhului este discriminatorie și lezează egalitatea de șanse dintre membrii comunității academice. Acordul unui episcop nu este statuat în nicio cartă universitară, iar invocarea sa aduce atingere autonomiei universitare și poate afecta performanța academică a unor cadre didactice. Afilierea la anumite asociații/ societăți științifice oferă membrilor anumite avantaje, cum ar fi liberul acces la baze de date științifice, schimbul de păreri și opinii cu omologi din lumea întreagă. De aici rezultă progresul profesional, autoperfecționare și, implicit, șansa de a evolua spiritual.

A doua interdicție din primul paragraf se referă la condiționarea participării la evenimente teologice internaţionale ca vorbitori. Acordul scris al chiriarhului și binecuvîntarea (aprobarea) Patriarhului României aduce în prim-plan dreptul la liberă circulație al persoanelor, stipulat în Constituția țării, Art. 25: „Dreptul la liberă circulație, în țară și în străinătate, este garantat. Legea stabilește condițiile exercitării acestui drept" [online]. Prin urmare, Hotărîrea Sfîntului Sinod al Bisericii Ortodoxe Române, dată în ședința de lucru din 24 mai 2018 (Temei nr. 4761 / 2018), deși nu are caracter de lege, nefiind publicată în „Monitorul Oficial”, se prevalează de aceasta, prin impunerea sa în mediul universitar, pentru teologii ortodocşi.

A treia interdicție implicită din primul paragraf aduce atingere libertății de exprimare, înscrise de asemenea în Constituția României, Art. 30: „(1) Libertatea de exprimare a gîndurilor, a opiniilor sau a credințelor și libertatea creațiilor de orice fel, prin viu grai, prin scris, prin imagini, prin sunete sau prin alte mijloace de comunicare în public, sînt inviolabile. (2) Cenzura de orice fel este interzisă” [online]. Acordul scris al Chiriarhului și binecuvîntarea (aprobarea) Patriarhului României nu pot fi interpretate altfel decît ca o formă abilă de cenzură, mascată de datoria preoților de a face ascultare canonică față de superiorii ierarhici. Dacă din punct de vedere religios acest paragraf are temei, întrucît cei hirotoniți au obligația de a da ascultare şi de a se supune necondiţionat ierarhilor, din perspectivă universitară se dovedește a fi o constrîngere subiectivă, discreționară și nefundamentată științific. Conform Hotărîrii sinodale a BOR, cadrul didactic dintr-o facultate de teologie este evaluat avant la lettre de un episcop care nu e obligatoriu să aibă o pregătire științifică și didactică serioasă, nici nu face parte dintr-un for academic recunoscut internațional ${ }^{8}$. Prin urmare, candidatul nu va fi evaluat după criterii științifice, obiective, în conformitate cu cerințele academice ale unui eveniment științific internațional, ci subiectiv, după criterii confesional-dogmatice. Atribuirea de puteri decizionale discreționare unor episcopi care nu au deseori expertiza necesară unei evaluări riguroase, imparțiale și care, în plus, nu beneficiază de un comitet științific performant pentru a-i sprijini în demersul de a binecuvinta/ respinge un potențial participant la un eveniment științific internaţional nu ar avea ce să caute în spațiul universitar contemporan. S-ar putea contraargumenta că episcopul beneficiază de suportul unor consilieri și ia decizii prin consultarea acestora. Totuşi, majoritatea consilierilor episcopali sînt aleși pe criteriul „ascultării față de chiriarh”, adică al obedienței. Nu primează calitatea intelectuală, ci, eventual, cea duhovnicească. Altfel spus, știința este inferioară religiozității.

Așa cum am subliniat și în alt studiu, „imixtiunea Bisericii în problemele învățămîntului de stat, laic este inacceptabilă, deoarece nu aceasta este ordonator principal de credite" (Felecan \& Munteanu Siserman, 2018, p. 178). De vreme ce o episcopie nu își asumă cheltuielile de participare ale unui universitar la un eveniment științific internaţional (i.e. taxă de participare, cheltuieli de transport, cazare, diurnă etc.), nu ar avea dreptul moral de a-i condiționa participarea, cu atît mai mult cu cît aceasta este o opțiune personală, legată de capacitatea intelectuală, științifică a unui cercetător sau de posibilitățile sale materiale. Se aduce atingere dreptului unui cadru didactic de a-și alege evenimentele științifice la care să participe, de a se deplasa la locul desfășurării acestora, fiind nevoit să se supună unui posibil drept de veto prealabil din partea unui chiriarh. O conferință/ un congres internațional (ă) are un comitet științific alcătuit din

\footnotetext{
${ }^{8}$ Pot exista excepții, care, însă, întăresc regula. Un exemplu fericit este al arhiepiscopului și mitropolitului Andrei Andreicuț, profesor universitar la Universitatea Babeș-Bolyai din Cluj-Napoca şi la Universitatea „1 Decembrie 1918” din Alba Iulia și, totodată, membru al Academiei de Științe și Arte din Salzburg (Austria).
} 
personalități competente în domeniu, se bazează pe un sistem de evaluare blind peer review, care asigură selectarea obiectivă a lucrărilor și, implicit, a participanților. Dar Sinodul BOR arogă drepturi mai mari unui episcop, fără să se amintească dacă a fost cooptat sau nu în comitetul științific al evenimentului pentru care trebuie să-și dea acordul scris. Altfel spus, se anulează obiectivitatea și se impune subiectivismul drept criteriu preliminar al oricărui demers științific internațional.

Pe de altă parte, selecția cercetătorilor care doresc să participe la evenimente științifice internaţionale, statuată printr-o hotărîre a Sinodului BOR, pune în opoziție normele interne bisericești cu autonomia mediului universitar. Putem exemplifica printr-un pasaj extras din Carta Universității Tehnice din ClujNapoca, la care îmi desfăşor activitatea: „Universitatea este un spațiu liber de ingerințe, presiuni şi constrîngeri politice, religioase (subl. n.) şi de putere economică, exceptînd constrîngerile de natură ştiinţifică, legală şi etică. Membrii universității sînt protejați față de cenzură, manipulări, persecuții, în condițiile respectării standardelor ştiințifice şi responsabilităților profesionale. Orice membru al comunității universitare trebuie să evite lezarea libertății celorlalți, pe baza respectului pentru diferențe” (p. 40).

S-ar putea aduce contraargumentul că un preot are obligația să-l asculte pe superior, adică pe episco-

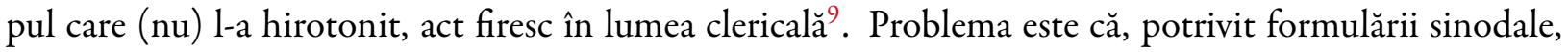
hotărîrea se referă la teologii români ortodocși, nu la preoți. Pot fi teologi care să nu fie preoți, care să-și desfăşoare activitatea exclusiv pe tărîm științific, în mediul universitar, așa că orice constrîngere de tipul celei existente în textul analizat este restrictivă și absurdă. Se trece cu vederea libertatea academică și se confundă teologii cu persoanele consacrate. Normele interne bisericești nu pot avea valabilitate/ aplicabilitate în mediul universitar, întrucît Biserica reprezintă o instituție conservatoare, ancorată în dogme vechi de aproape două mii de ani, pe cînd universitatea este exponenta progresului, a inovării. Îngrădirea libertății de exprimare prin limitarea dreptului de participare la evenimente științifice este nu doar ilegală, contrară cartelor universitare din orice țară civilizată, democratică, ci și imorală, lipsită de etică.

Nici în Evul Mediu universitarii nu au acceptat astfel de constrîngeri, însă, în secolul XXI, BOR le impune pentru teologii români ortodocşi. Oare nu are încredere în ei sau dorește un control absolut al clerului inferior ierarhic? Un demers firesc ar fi fost să fie adoptată o hotărîre privitoare la cofinanțarea participării la evenimente științifice internaționale, astfel încît un număr cît mai mare de teologi români să aibă acces la diseminarea ideilor în lumea științifică. Atitudinea BOR este nu doar lipsită de etică, ci atinge însăși esența spiritului academic: „Officially, the central business of universities is the creation and communication of knowledge, which can be called public knowledge" (Ziman, 1968 apud Martin, 2017, p. 11). Esența menirii dascălului a fost surprinsă de Bertrand Russell încă de la mijlocul secolului trecut: "The teacher, like the artist, the philosopher, and the man of letters, can only perform his work adequately if he feels himself to be an individual directed by an inner creative impulse, not dominated and fettered by an outside authority" (Russell, 1950, p. 159). Cercetătorul, la fel ca profesorul, are o menire liberală, rolul său în societate este de a disemina rezultatele obținute în munca sa în publicaţii științifice și la diverse manifestări științifice. Pentru aceasta, el ar trebui sprijinit să aibă acces la cele mai noi realizări din domeniul său de activitate, nu să fie constrîns, arbitrar, de un superior ierarhic. Așa cum un conducător de doctorat are rolul "to support the student in developing capacities, for example for collecting information, analysing data, formulating hypotheses and writing up findings, depending on the discipline" (Martin, 2017, p. 12), la fel un episcop sau însuşi patriarhul BOR ar trebui să susțină cercetătorul teolog să-şi disemineze ideile în lumea științifică internațională, fără niciun fel de îngrădire. Participarea la o conferință internațională reprezintă manifestarea vizibilă a performanței în cercetare.

Hotărîrea Sinodului BOR de a controla îndeaproape calitatea „subordonaţilor” de a fi membri în asociații sau fundații teologice ortodoxe, interconfesionale sau interreligioase internaționale, ori de a participa la evenimente teologice internaționale ca vorbitori denotă nu doar o formă de cenzură, ci și neîncrederea în cadrele sale de elită, capabile să iasă din cercul național strîmt, confesional și să interacționeze cu teologi

${ }^{9}$ La fel ca în armată, și în Biserică se invocă adesea virtutea ascultării, însă nu neapărat cu referire la integritatea dogmatică și morală a Bisericii, ci, deseori, la ascultarea obedientă față de superiorii ierarhici, considerați infailibili [online]. 
din alte țări, culturi și de alte confesiuni sau religii. Lipsa de încredere se manifestă a priori, din teama de a nu fi lezată imaginea BOR în lume, în mod particular, și credința ortodoxă, în general. Totuși, potrivit lui Corlett, „those who seek to curtail higher educational academic freedom rights by way of censorship stand on unreasonable ethical grounds to do so [...] Offensiphobia ought to be rejected as it is unsupported by the balance of reason" (Corlett, 2018, p. 113). Dacă restricționarea teologilor de a avea acces liber la evenimente științifice internaționale s-ar putea interpreta și ca un exces de prudență din partea Bisericii, pentru mediul academic echivalează cu îngrădirea libertății. Reprezintă un atentat la vizibilitatea internațională a cercetătorilor și a realizărilor acestora, la schimbul de informații neîngrădit. Trebuie lăsat universităţilor dreptul de a-și gestiona treburile interne, didactice, de cercetare și de management. Demonstrarea calităţii de cercetător a unui profesor de teologie se impune a fi cuantificată prin criterii științifice, nu prin cele religioase. Consider că este nepermis ca normele interne bisericești să ingereze, să aibă valabilitate în mediul universitar, întrucît, astfel, ar aduce atingere libertății academice, în special, și libertății de expresie, în general. Libertatea individuală este strîns legată de libertatea academică ${ }^{10}$. Ingerința BOR în mediul universitar, într-o formă continuată, poate fi interpretată ca un atac susținut la autonomia universitară, ca o dorință de a-și subordona și de a controla mediul academic, sub pretextul gestionării problemelor teologice. Cunoscînd puterea și influența BOR în societatea românească, profund conservatoare, nicio universitate nu are curajul de a o înfrunta, de a-i arăta limita peste care nu se poate trece, fără a știrbi autonomia universitară. Prin poziția dominantă în România și prin abuz de putere, BOR intimidează mediul universitar, în general, și pe teologi, în special, astfel încît să-şi asigure supremaţia în continuare, să aibă siguranța că nu vor trece granițele criticile unor teologi la adresa acesteia sau, cel puțin, nu în lumea ştiințifică internațională.

\section{Concluzii}

Hotărîrea Sinodului BOR este discutabilă, deoarece lezează libertatea academică. Luînd ca model analiza lui Corlett din studiul Offensiphobia (2018, p. 120), se aduce atingere "at least three general categories: rights to freedom of expression in research, rights to freedom of expression in teaching, and rights to freedom of expression in service”. Sînt încălcate drepturi ale omului (de asociere, de liberă circulație și de exprimare), în corelare cu drepturi ale cercetătorului universitar: „There is also the right to freely attempt to publish on which topics and in which journals and on which presses one chooses" (Corlett, 2018, p. 120). Încercarea Bisericii de a căuta eliminarea erorilor teologice sau posibile critici la adresa sa echivalează cu o formă de cenzură inacceptabilă în lumea academică a secolului XXI. Este o problemă etică, iar uniformizarea gîndirii teologilor români este nu doar imorală, ci și neproductivă, chiar umilitoare. Așazisul peer review preliminar al unui episcop legitimează în sînul Bisericii cenzura. Restrîngerea treptată a drepturilor neurmată de nicio formă de protest din partea mediului academic românesc poate duce la proliferarea unor astfel de hotărîri nedemocratice și la întărirea rolului Bisericii în postura de conducător din umbră al societății românești. Abuzul de putere dominantă face ca BOR să nu țină seama de legile în vigoare și să ia hotărîri care ating libertatea individuală și libertatea academică deopotrivă. Lipsa luării de atitudine de către societatea românească, în general, și de către mediul universitar, în special, denotă o formă de complicitate tacită. Din păcate, cei care s-au opus individual acestor măsuri au avut de suferit: fie li s-au luat orele predate la teologie, fie li s-a îngrădit dreptul la promovare, la diverse recompense legale (gradație de merit, de ex.), fie sînt hărțuiți, pentru a fi convinși să renunțe la „lupta” lor sau pentru a li se inocula ideea că orice demers ar întreprinde este unul don quijotesc.

Consider că descurajarea/ atitudinea defensivă și acceptarea unor astfel de hotărîri sînt contraindicate și că avem datoria morală de a semnala derapajele inacceptabile pe care le aduc mediului universitar românesc și cercetării științifice anumite hotărîri ale Bisericii Ortodoxe Române.

\footnotetext{
${ }^{10}$ Corlett (2018) consideră că „academic freedom is a species of freedom of expression” (p. 144).
} 


\section{Bibliografie}

\section{A. Referințe}

Corlett, J.A. (2018). Offensiphobia, în „The Journal of Ethics”, 22 (2), p. 113-146, Crossref.

Felecan, O. \& Munteanu Siserman, M. (2018). Interpretări sociolingvistice ale unui text administrativ emis de instituții bisericești, în „Text și discurs religios”, 9, p. 173-184.

Martin, B. (2017). Defending university integrity, în „International Journal for Educational Integrity”, 13 (1), Crossref.

Russell, B. (1950). Unpopular Essays, Simon \& Schuster, New York.

Ziman, J. (1968). Public knowledge: an essay concerning the social dimension of science, Cambridge University Press, Cambridge.

B. Webografie (accesată în iulie 2018)

Agenția Română de Asigurare a Calității în Învățămîntul Superior (ARACIS) [online].

Constituția României [online].

The Constitutional Court of Romania (CCR) [online].

Cuvintul Ortodox (2018). Ascultarea, pretextele și abuzurile ei - părintele Savatie pune punctulpe I [online].

European Association for Quality Assurance in Higher Education (ENQA) [online].

European 2uality Assurance Register for Higher Education (EQAR) [online].

Institutul Național de Statistică România (2013). Ce ne spune recensămîntul din anul 2011 despre religie [online].

Petitieonline.com (2014). Impozitarea veniturilor Bisericii Ortodoxe Române [online].

Schmitt, O.J. (2018). Ob Faschisten oder Kommunisten - Rumäniens orthodoxe Kirche war stets eine Dienerin der Macht, în „Neue Zürcher Zeitung” [online].

WIN-Gallup International (2012). Global Index of Religion and Atheism [online]. 